\title{
The problem of language and reality in Russian modernism: The conception of mirotvorchestvo in A. Remizov's Rossiya v pis'menah
}

\author{
Marina Aptekman \\ The Department of Slavic Languages, Brown University \\ 6 Rhodes Lane, Foxboro, MA 02035, USA \\ e-mail: marina_aptekman@brown.edu
}

\begin{abstract}
Alexej Remizov is usually regarded by literary critics as a Symbolist rather than a Futurist writer. However, I would posit that Remizov similarly to the Futurists viewed language as "logos," bozhestvennii glagol. According to the mystical interpretation of the famous words "At the beginning there was Word and the Word was with God and the Word was God", when God was creating the world he named the objects, and these abstract names became a force for the appearance of an object in physical reality. In the light of these words, The Medieval mystical and magical philosophers claimed that one could restore the divine language of Creation, possess the ability to create objects anew, and thereby become Creator himself. One can argue that a major goal of Remizov was similar to that of his Medieval predecessors: to reveal the mystical power of language in order to create, not to describe reality. The paper analyzes three chapters from Alexej Remizov's Rossiya v pis'menah, a book which can be read as a manifesto of Remizov's attitude toward language and reality, and discuss possible sources that might have influenced Remizov in his attitude towards language.
\end{abstract}

Alexej Remizov is usually regarded by literary critics as a symbolist. Although critics sometimes compare Remizov's work to Futurist writings, especially to Hlebnikov, at first glance there is not very much in common between the art of Remizov and that of the Futurists. Remizov's aim is to reveal the language of the Old Russian times; the works of Futurists are full of neologisms. Remizov is looking into the past, while Futurists are mostly interested in the future. However, upon careful analysis of Remizov's works, one can observe a strong similarity between the attitudes of both the Futurists and Remizov toward the role of language and reality in literature. It has been 
already mentioned by $\mathrm{H}$. Baran that both Remizov and Hlebnikov were interested in the study of myth (Slobin 1987: 190). Baran notes that both Remizov and Hlebnikov are trying to create new myths on the basis of old ones. He connects this tendency with the fact that these writers also try to create new words using old roots and to play in both slovotvorchestvo and mifotvorchestvo (Slobin 1987: 191). However, the interest in the creation of neo-mythology was not just a feature of Remizov or Hlebnikov's works. One can argue that this interest was among the most dominating in the artistic perception of the Silver Age in general, from symbolists to futurists. ${ }^{1}$ I would argue that it is not quite "mytho-" but mirotvorchestvo that unites Remizov and the Futurists, that is to say, the similar attitude of Futurists and Remizov toward language as a tool for the creation of a new personal world through their own personal language. I would posit that Remizov as well as the Futurists viewed language as "logos", bozhestvennyj glagol, the mystical word of God, about which St. John talks in his Gospel. According to the mystical interpretation of the famous words "At the beginning there was Word and the Word was with God and the Word was God" when God was creating the world he named the objects, and these abstract names became a force for the appearance of an object in physical reality. This conception of logos, although existing from the third century, became extremely popular in the Middle Ages and early Renaissance. Medieval mystical philosophers, especially those connected with magic and alchemy, claimed that one could restore the divine language of Creation. If one were to succeed in doing so, he would possess the ability to create objects anew, thereby becoming a Creator himself.

One can argue that a major goal of Remizov as well of the Futurists was similar to that of their Medieval predecessors: to reveal the mystical power of language in order to create, not to describe reality. In my paper I will analyze three chapters from Alexej Remizov's Rossiya v pis'menah, a book which can be read as a manifesto of Remizov's attitude toward language and reality. I will also discuss possible sources that might have influenced Remizov in his attitude towards language, especially those that have their roots in the mystical linguistic doctrine of Kabbalah.

Kabbalah (originally the Hebrew word tradition) is an esoteric philosophy that developed among Jewish philosophers in Spain in the early Middle Ages. The central teaching of this philosophy is the idea

See for example, Mints 1979. 
that God manifests himself in the form of infinite Light, in Hebrew zohar. The principal idea of Kabbalah lies in the conception of Creation. The whole process of creation is shown as a process of ten impulses of the Divine Light, each one of which marks a new stage in the creation. These ten stages are called spheroth. Kabbalah claims that the Divine light manifests itself in the form of the divine Word, Logos. ${ }^{2}$ This belief resulted in the concept of linguistic mysticism, and in the fact that by the beginning of the sixteenth century Kabbalah began to develop into two branches: the theoretical and the practical. While the aims of theoretical Kabbalah were purely moral and led by the wish to find the answers to questions about the nature of Humanity and the role of God in Nature, practical Kabbalah was interested mainly in the linguistic mystical doctrine of zohar. The Jewish practical Kabbalah later developed into a Christian one, which was a combination of original Kabbalah, Neo-platonic philosophy and Christian mysticism. It brought forth the Neo-Kabbalistic belief that all the secrets of divine and earthy beings can be decoded and revealed by the manipulations of various letters in the alphabet. Practical Kabbalists asserted that each letter in Language represented a physical or spiritual quality of either God or a Human, and claimed that if one took letters as a secret code of creation, by manipulating them one could find the original Divine Word for an object, and, with its help, create this object anew. The following passage from the book Hayye ha Olam kha Baa written by the famous Jewish Kabbalist philosopher Abraham Abulafia may serve as an example of the linguistic mystical approach to Kabbalah:

Let your garments be white. If it's night, let everything be illuminated by numerous lamps. Then start combining the letters individually or a few at a time. Move them around until passion ignites in your heart. When the flame of passion has been lit in your heart by moving the letters, you will understand things that you ordinarily wouldn't be able to see. ${ }^{3}$ (Eco 1998: 214)

In their mystical attempts, Jewish Kabbalists preferred to use the interpretations of the ancient Hebrew texts rather than newer Jewish writings because of the belief that the Past is closer to the revelation of the divine secrets than the Present. In Christian Kabbalah the inter-

\footnotetext{
2 For a detailed study of Kabbalah see Sholem 1961. See also Idel 1988.

3 All the translations presented above are mine, except for the translation of the quote from L. Tolstoj's War and Peace.
} 
pretations of the ancient Jewish writings were replaced by the interpretations of early Christian Apocalyptic texts. ${ }^{4}$

Magicians and alchemists called Kabbalah "the secret knowledge," which they alone possessed. However, this "secret knowledge" was widely propagated in a number of manuscripts, which later became very popular among the German mystics and Pietists and reached Russian intellectuals through Free-Masonic contacts in the mid-eighteenth century. It would be appropriate here to quote a passage from a book by German Ficktauld, Kabbalah Mystica Naturae, presented in the archive of the famous Russian eighteenth-century Mason Count Elagin. The following description of Kabbalah cited from the book explains how Elagin might have seen Kabbalistic philosophy:

Kabbalah is a natural philosophy which is devoted to the understanding of the soul, astral bodies, celestial spirits, elements, and, most of all, the divine light. Letters and syllables are the most significant part of Kabbalistic studies because letters are the home of spirits and every spirit originates from a specific letter. ${ }^{5}$

The age of Modernism was a time of strong revival of the interest in everything mystical and magical. The birth of French symbolism involved, using the words of Bernice Rosenthal (1997: 21) "a rediscovery and popularization of alchemy, magic and Kabbalah". This revival owes much to the efforts of Eliphas Levi, a Catholic priest, who, using a Jewish pseudonym, both translated the most famous late Medieval and early modern books on occultism, such as the works by Agrippa, Paracelsus and Boehme, and wrote his own books on magic and practical Kabbalah. The French interest was quickly carried to Russia where, as Rosenthal notes in the introduction to the book The Occult in Russian and Soviet Culture:

The occult was a remarkably integral part of pre-revolutionary Russian culture. Occult doctrines appealed to artists, writers, and political activists. Avant-garde poets and painters were intrigued by the idea of a fourth dimension. Philosophers and lay theologists explored the occult in their quest for new religious truths. (Rosenthal 1997: 21)

4 For a deeper analysis of the influence of Jewish mysticism on late Medieval and Renaissance magical practices see Faivre 1992. Also, an interesting view of the relations between Jewish Kabbalah and Christian Kabbalah is presented in Idel 1992.

5 The quotation is from an unpublished manuscript source from the P. M. Kaznacheev archive, a private collection of B. Kerdimun. 
It was the Modernists and especially the Symbolists who returned to the belief of the magic power of the Word, a creed that traces back to Kabbalist linguistic mysticism. In the mid-1880s, A. Rimbaud came up with the idea that sounds can express emotions just as words do, and that they can even have colors. The idea was followed eagerly in Russian Modernist literature, not only in symbolist poetry but in such "younger" movements as akmeism and futurism. For example, in his poem Na Venere, akh, na Venere Nikolaj Gumilev expresses the similar belief that sounds can express emotions:

\author{
На Венере, ах, на Венере, \\ Нету слов обидных и властных, \\ Говорят жители на Венере \\ Языком из одних только гласных. \\ (Gumilev 1987: 185)
}

The same idea can be seen in the Modernist literature up to the early twenties. In 1921, a symbolist Fedor Sologub, for example, shows his longing for "vowel language" in a following way:

\title{
Родился бы я на Мадагаскаре \\ Говорил бы наречием где много “а” \\ Слагал бы стихи о любовном пожаре \\ О нагих красавицах на острове Самоа. \\ (Schmid 1999: 645)
}

The symbolists' and akmeists' attempt to prove that not only words but also letters can bear emotional and even semantic power, was followed by the futurist writers. Futurists revived the linguistic theory of creation, declared that Art is not objective but creative and not only brought back the Kabbalist idea that the Divine language differs from the human one, but also argued that, using the words of A. Kruchenyсh "художник волен выражаться своим собственным языком ибо творец индивидуален” (Shklovskij 1991: 179). In 1919, V. Shklovskij directly compares transrational language to an incantation, i.e. to a linguistic segment, which seems meaningless but actually bears an important secret meaning: a meaning, which is creative, and not descriptive. ${ }^{6}$ The interest in the occult power of language went hand in hand with the interest in everything old and long-forgotten:

\footnotetext{
6 For the development of the similar practices in the Renaissance kabbalistic magic, see Yates (1964).
} 
medieval legends, fairy tales and especially old books and manuscripts. As G. Meyrink observes: "Strange things of mysterious origin - parchments covered with secret signs, tattered manuscripts [...] they draw our attention like magnets by creating a mysterious connection with the yet undiscovered depths of the human soul" (Meyrink 1992: 19).

Rossiya $v$ pis'menah by A. Remizov appeared at the peak of this interest. The book is composed as a chain of old documents and engravings, discovered and re-told by the author. In the book Remizov's Fictions: 1900-1921, G. Slobin finds that "in his utmost regard for the word in all its facets, including its magic and music, Remizov was close to the symbolist notion of language as a tool of creative cognition" (Slobin 1991: 30). In the article "Неизданная книга Мерлог", D'Amelia notes that "The very name of the book leads the reader to the idea about the recreation of the reality through the language in which lexical meaning is united with the image created by the disposition of letters and words on a page" (Slobin 1991: 148). However, neither D'Amelia nor other critics have noticed that in such an approach to old texts Remizov follows the ideas of the practical Kabbalistic theory and regards the language as a mystical and magical tool that helps to reveal the secrets of the long-forgotten Past. A good example of this role of language is the chapter called “The Trunk” (“Сундук”).

The trunk of Remizov's story is clearly a bearer of something secret and long-forgotten. As the narrator says: "There was only one thing known about the trunk, that it bore the belongings of our greatgreat-grandfather Dmitri Filosofov — some old rags ("какая-то ветошь ')" (Remizov 1982: 82). This trunk has outlived all its owners, the first of whom died in 1779. However, nothing of what was placed in the trunk, has survived decay. When the trunk is opened, one cannot find anything in it, except for old rotten garments. The only way to reveal the secret and to find out what was in the trunk is through language: the list of belongings that was left inside and is still in good condition. This is strange because paper is no more resistant to decay than other materials. It seems that the survival of the list bears a significant symbolic meaning: the only thing that has been left from the past is the text. This text, a simple list of belongings, is transformed into a magical document, which helps to re-construct something been dead for centuries. The idea of the list as a magical spell finds support again in the last lines of the story. "От сундука ничего не осталось, а записка у меня, и хранит ее волк-самоглот“" 
("Nothing is left from the trunk but the note guarded by a fairy wolfsamoglot") (Remizov 1982: 84). The wolf, although a toy-figure, is definitely a fairy-tale guard, which protects a magical treasure. This notion only stresses the fact that for the narrator the list, "zapiska" is clearly such a treasure.

"Reality is created by Art" (Kodryanskaya 1959: 197), Remizov writes in one of his notes. He declares that "the retelling is never a reproduction but an attempt to recreate a living being" (Kodryanskaya 1959: 196). In his attempt to re-create the past and to create the new "past in the present" suggested by Sunduk, letters for Remizov are of no less, if not of more importance than words. Much has been written about Remizov's interest in the graphical side of a letter. D'Amelia, for example, claims that for Remizov semantic meaning can be present in a letter just as in a whole word. She compares Remizov's view of the role of letters to Hlebnikov's and Kruchenych's manifesto "Letter as Such", saying that "Remizov deconstructs a page into separate parts like Hlebnikov in his manifesto on the deconstruction of language or Filonov in his art works" (Slobin 1986: 147). From this comparison it is only one step to Shklovskij's definition of transrational language, in which a letter revives its symbolic origin, and, in this way, everything that seems meaningless at the first glimpse becomes a bearer of creative mystical power. ${ }^{7}$ However, D'Amelia does not take this step. She sees an origin for Remizov's attitude toward the "meaningful letters" in the Japanese or Chinese art of hieroglyphics. Yet the hieroglyphics themselves do not bear any mystical power. They are used to describe and not to create. For Remizov, on the other hand, a letter is always an entrance into a living life of language, an exit from three dimensions into four. It seems that in order to understand the role which letters play in Remizov's work, one should consider the major interest of his whole life: a passion for the glagolitic alphabet.

J. Obatnina finds that "The glagolitic alphabet became a passion for Remizov, who at the beginning stages of his studies filled an entire notebook with his glagolitic exercises. For Remizov, the glagolitic alphabet played the role of a sacred language" (Obatnina 1996: 183).

7 The same idea can be seen in Remizov's Fictions:1900-1921 by G. Slobin. Slobin compares Remizov to his contemporaries Belyj and Hlebnikov, and says that just like them Remizov "rediscovered the magic of sounds and words" in a process of literary creation akin to a shaman's "transcendence of the profane condition". 
However, the glagolitic alphabet originally bore sacred and mystical elements. In the article "Славянская азбука" L. Savelieva explains that glagolitsa is a reflection of the spirit of Medieval linguistic mysticism on the Slavic ground, which maintains "a deep mystical union of letters being bounded to each other" (Savelieva 1994: 213). According to the symbolic interpretation of Savelieva, each letter in glagolitsa has a semantic meaning. When placed in order as a text and translated into Modern Russian, these letters look like a prayer or a poem with powerful philosophic implications. Moreover, besides the direct semantic meaning, each of these letters bears not only a symbolic semantic but also a numerical connotation. Of particular importance in the glagolitic alphabet is the letter $A z$. It differs considerably from the Greek Alfa, and looks more like a transformation of the Hebrew alef, a mystical letter suggesting the beginning of creation. In Medieval Hebrew, used by Christian as well as Jewish Kabbalists, the letter alef represented both ani (myself, i.e. everything) and ein (nothing), and was considered "the symbol of everything which is both below and above and which is the beginning of everything" (Sholem 1991: 37-39). In a description of the meaning of $A$, Savelieva strongly echoes the Hebrew symbolic explanation of alef, noting as follows:

A cosmogonic model of the letter 'Az' is a pattern connected with spatial orientation, where up and down are regarded as spritual and material, respectively. 'Az' becomes a symbol of human ego and at the same time an allegory for the origins of human development. Thus, one understands the first and, undoubtedly, the most sacred letter of the glagolitic alphabet as a symbol of world building founded by the creator of the Russian tradition of the written word in the alphabetical text. (Savelieva 1994: 213)

Only through the understanding of "azbuka" as a sacred mystical text, can one understand the significance of Azbuka in Rossiya v pis'menah.

Azbuka concludes Rossiya v pis'menah. V. Hlebnikov argues in his "Letter as Such" that letters can have semantic meanings. Each letter means a different emotion or a different force. This makes language a living being, a symbol of life. The same attitude toward the role of letters in language can be seen in Remizov's Azbuka. While describing his work on the book, Remizov writes in a note that his aim is to represent Russia as a living being: “как живое существо” (Slobin 1986: 147). The last chapter of Rossiya $v$ pis'menah becomes the terminating symbol of the whole text: of Russia as a living being, where the moral symbolic concept of this being is based on the 
Russian language, in the Azbuka. Thus, the alphabet becomes the symbol of life. For Remizov, like for Cyril, the inventor of the glagolitic alphabet, the central letter of this "life" is "AZ," the letter of creation. "Аз есьм свет миру" (Az is the Light of the world), the narrator declares, and develops this statement by showing the creative power of this letter:

Сколько слез - тех когда стукнулся — отделился от вещи другой нет, изволь из воздуха создать новую вещь. И этот “аз” тебе меняет лицо, глаза, взгляд. (Remizov 1982: 210)

In Azbuka Remizov plays with letters just as the followers of the grapho-semantic conception of Kabbalist writings did in their attempt to find a spell that would help to create a new object. He places together in three rows words with identical meanings, written in four different "azbukas" in German, and in Russian, as in order to discover whether or not the reality would differ if the form of the letter had been changed. He also places together in parallel rows letters from distinct languages that differ in their graphic form but are vocally similar, as if he tries to check whether the reality depends on the letter or on the sound. German and Russian interrupt each other not only in the azbuka, but also in the text of the novella itself, creating a mixture of languages. It seems that letters, sounds and even graphical devices become for Remizov more important than the semantic meaning of the words. In these letters and sounds he sees a union that creates "живое слово", a word which is not descriptive, but creative, a living being. As Remizov himself says: "Загадка языка, буквы прописные, строчные, сложи двоеписьменные, сложи троеписьменные, титла, ярок, кавыка, удивительная, вопросительная, вместительная" (Remizov 1982: 212).

Upon looking at the text of Remizov's Azbuka one can see it not as a literary, but more as a mathematical text, a formula. ${ }^{8}$ As has been mentioned above, in both Christian and Jewish Kabbalah the semantic meaning of the letter also depends on the number it represents. Numerology is one of the major features of any linguistic mystical theory. That may be the central reason why numbers played such an

8 The passage given above shows Remisov's interest not only towards letters but also towards the graphical signs, which were used in early Old Church Slavonic to show a grammatical category of the word or a correct pronunciation. The device can be paralleled to the system of graphical signs, nekudot, used in Hebrew and widely exploited by practical Kabbalists. 
important role for the futurists, especially Hlebnikov. ${ }^{9}$ In numbers the Futurists saw an active power, which could help them to reveal the secret of creating a new world. It seems that the corresponding numbers of the letters in three different alphabets are also important for Remizov, and that he is well aware of the numerological side of language. The chapter Tsifry, which is significant for an understanding of "Rossiya v pis'menah" as a whole, supports this idea.

Tsifry expresses Remizov's strong interest in numerology. “Прельстительная слагаемость цифр, тайность знаков, сколько страсти и какая волшебная притягательность"” (Remizov 1982: 192). The chapter shows not only Remizov's interest in numerology, but also some practical knowledge. Remizov seems to know the Kabbalistic meanings of some of the numbers: 6 - earthy life, 7 the kingdom of angels, 3 - heavenly knowledge, 666 - the number of mankind (страшное число человеческое) (Remizov 1982: 192).

Christian magical Kabbalistic numerology is based on the system 3-7-12, where seven means the number of angels sitting at the foot of the divine throne, three stands for the Trinity, and twelve symbolizes the unity of life both on heaven and earth. $3+7+12$ equals 22 , the total number of the faces of the Deity. Multiplied by the number three, the symbol of the Trinity, these numbers equal 66. This 66 , which later started to be written 666 (probably to stress again the importance of the Trinity) is the number that symbolizes the Creation. ${ }^{10}$ In Hebrew all letters already bear simultaneous numeral meanings. Other languages, and among them Russian, had to be deciphered so that each letter would receive a parallel, mystical, number. In Russian this work has been done through glagolitic, not through the Cyrillic

9 See Nikolaj Bogomolov's “Об одном из источников диалога Хлебникова Учитель и Ученик" in Bogomolov 1999: 264-270. The interest towards numbers as a vivid part of language can be seen not only in Futurists but in the poetics of the Silver Age in general, for example in Gumilev's poem Slovo. Such an attitude again shows the intend of the writers of the time to follow the Renaissance pattern of the kabbalistic magic which regarded both numbers and letters (sounds) as two parts of one magical language. (See, for example, Reuchlin 1987, or Agrippa of Nettesheim, De Occulta Philosophia. See also Papus, Quabala as a later example of such a tradition.) However, Gumilev regards numbers as the subordinate part of the language, not as important as sounds are (не решаясь обратиться $\kappa$ звуку/тростью на песке чертил число...). Such view was quite common for the Silver Age poetics, and was changed only in futurist literature.

10 For a more detailed analysis of the role of numerology in Kabbalah see Sholem 1941. For the Christian magical interpretation of Kabbalistic numerology see, for example, Mathers 1989. See also Idel 1992. 
alphabet, so Remizov's interest in the mystical side of glagolitsa could have reinforced his interest in this subject as well as helped him in his knowledge of the numerical side of azbuka. Remizov's use of numerology in "Tsifry" also shows his knowledge of the role it has played in interpreting the Apocalyptic texts. He quotes the words from St. John's Apocalypse: "и послал мирови ангела кроткости" (... and he sent an angel of kindness to the world...), noticing that "according to the church calendar, every letter has a corresponding number. The sum of the numbers corresponding to the letters in Apocalypse produces the year of the birth of the emperor (Alexander I)" (Remizov 1982: 194). One can also notice the similarity between Remizov's interest in predicting or explaining things with the help of the numerological side of a text and the similar interest of Hlebnikov, for whom the mystical power of numbers went hand in hand with the desire to predict the Future.

In light of everything presented above, one can argue that Rossiya $v$ pis'menah shows that, in his ideas about language and reality, Remizov may indeed be more closely aligned with the Futurist literary philosophy than with that of the Symbolists. Rossiya $v$ pis'menah is a book about the priority of language over reality. The major problem that Remizov's book deals with is the ability of a writer to re-create something lost long ago or even to create his own reality through language, using both the literary and the numerological sides of it. Given such a task, the role of a writer becomes akin to that of a magician or a wizard, and Remizov himself is fond of such a definition. In his notes he mentions that he sometimes feels that through his works he gains access to "a strange, secret life of fantastic and unreal". In a note dated 1921, he suggests that he himself might have magical power. He mentions a day when he wished, leaving a building in which he had been strongly offended, to burn this house down - and the next day the building was really burned to the ground. The literary parodies of the first decades of the century always stressed this interest of the writer in magic and even demonism. One of the critical articles pictured Remizov as a lonely old man who

lives in a half-dilapidated little house and only admits those on whom he has placed a terrible and mysterious spell. He writes in a small dark room in front of a soot-covered hearth [...] a black cat rubs up against his feet, and the silence is suddenly disturbed by the harsh cries of an old owl. When he writes he dips his pen in a white skull filled with blood. What a horrible sight! (Obatnina 1996: 189) 
The question is whether Remizov could really be aware of the linguistic philosophy of practical Kabbalah, which would support the aforementioned observations. I believe that such a possibility may exist. The mystical trends that became popular in Russia during the first decade of the twentieth century resulted in the strong interest of Russian artistic intellectuals in Kabbalah, both Christian and Jewish. Theologists such as Pavel Florenskij and Sergei Bulgakov refer to Kabbalah when they look for the origins of the mystical concept of Sophia. The Jewish origin of Sophia is also presented in the works of Vladimir Solov'ev, whose concept of Sophia presents Sophia-Wisdom as Kabbalist Hokhmah, the second and the closest to God, sphera, which symbolizes the Divine Wisdom. J. Kornblatt in her article on Vladimir Solov'ev argues for the possibility that Solov'ev might have studied original Jewish Kabbalistic manuscripts in the library of British museum in London. She says in particular that

Kabbalah actually refers to a mystical practice that involves contemplation of the names of God found in Hebrew Scripture, often through numerical manipulations of the letters of the Hebrew alphabet... Its most development came in thirteenth century Spain, with the dissemination of the book of Zohar. The Zohar, which Solov'ev probably read in Latin translation, was written or perhaps partially complied by Moses ben Shemtov de Leon, but it was attributed to a great sage of the talmudic period, Shimon Bar Iohai. (Rosenthal 1997: 79)

However, with its general interest in magic and the occult, modernism primarily paid attention not to moral spiritual Kabbalistic concepts, like that of Sophia/Hokhmah, but to practical, mostly Christian, Kabbalah. ${ }^{11}$ By the end of the first decade of the century all of the major works of a French writer Papus, the central nineteenth-century popularizator of Christian Kabbalah, were introduced into Russian society. Remizov's profound interest in magic paralleled with his good knowledge of French, would most probably have led him to these works or to their interpretations in contemporary criticism, especially since they were very popular. In her article “Обезьянья великая и вольная палата: игра и ее парадигмы”, J. Obatnina notes that Remizov often sighed his letters and documents with the name of an imaginary king, Abrasacks. She argues that the origin of the figure of Abrasacks might be an article by I. Mansvetov, which Remizov

\footnotetext{
11 For the detailed study of the occultism and the Silver Age culture in Russia see Carlson (1993).
} 
read between 1907-1917. The article analyzes the Gnostic numeral explanation for the name of the Deity. According to Obatnina,

It follows from this article that the Kabbalistic name of the gnostic deity Abrasacks, when converted into corresponding numbers, corresponds in turn to the gnostic pleroma, which contains 365 eons, a reflection of the number of days in a year. Therefore, the mystical name of the king Abrasacks can also correspond to the main idea of Remizov's book Posolon', which describes the calendar year. (Obatnina 1996: 196)

Another way in which Remizov might be acquainted with Kabbalistic linguistic theories, either original or Christian, is Free-Masonry. Remizov seemed to know Masonic symbolism quite well through his friends who were involved in Masonry, for example M. Tereschenko who held a high rank in the Masonic lodge "Великого Востока народов России". The ideology of this lodge was influenced by Papus's own lodge in Paris. ${ }^{12}$ Some of Remizov's drawings express symbolism, that was strongly wide-spread in origin in Masonic or alchemic works, for example a snake that eats its own tail. ${ }^{13}$ In his letters, for example one dated February 1923, he even mentions his interest in Kabbalah, although he refers to it as the knowledge of ancient Persian magicians later adopted by Masonic philosophers. Moreover, in the chapter Tsifry one finds an interesting similarity between the numerological interpretation of the text about the Emperor Alexander with that of the similar interpretation of a Masonic text found by Pierre in a well-known passage from Tolstoj's War and Peace. In particular, Tolstoj writes that:

One of his brother masons had revealed to Pierre the following prophecy relating to Napoleon, and taken from the Apocalypse of St. John.

In the Apocalypse, chapter thirteen, verse seventeen, it is written: "Here is wisdom...count the number of the beast, for it is the number of the man, and his number is six hundred three score and six..."

And in the fifth verse of the same chapter: "And there was given unto him a mouth speaking great things and blasphemies, and power was given to him to continue forty and two months."

12 For the influence on Papus' activities on Russian artistic milieu of the Silver Age and for the history of his Martinist Lodge in Russia see Serkov 1997.

${ }_{13}$ For the use of this emblem in alchemic symbolism see Rabinovich 1979. 
If the French alphabet is treated like the Hebrew system of enumeration, by which the first letters represent the units, and the next the tens and so on, the letters have the following value:-

a b c d e f g...

$1234567 \ldots$

Turning out the words l'empereur Napoléon into ciphers on this system, it happens that the sum of these numbers equals 666, and Napoléon is thereby seen to be beast prophesied in the Apocalypse. This prophecy made a great impression on Pierre. He frequently asked himself what would put an end to the power of the beast, this is of Napoléon; and he tried by the same system of turning letters into figures, and reckoning them up to find an answer to this question. (Tolstoj 1995: 621)

V. Shklovskij even notes that a famous fraternity, "Великая Обезьянья Палата", “was created by Remizov in the style of a Russian Free-Masonic Lodge" (Shklovskij 2000: 24). The palata was definitely a game, but a game which bore many symbolic features, and had much in common with a Masonic lodge. It was ruled by a council of seven Monkey Counts and governed by a King named Asyka. The entrance to the fraternity could be reached only with the knowledge of three passwords. Remizov used the glagolitic alphabet and a special signature to write and to sign documents connected with the fraternity. J. Obatnina believes that Remizov's fraternity was a parody of a Masonic union and that Masonic symbolism did not have a serious influence on Remizov's literary art. However, I would argue that most of the symbols created by Remizov in "Великая Обезьянья Палата", may be explained only through the perspective of his literary works, and especially through Rossiya $v$ pis'menah. The council of seven counts in palata may well have its origin in Masonic ranking, but also strongly echoes the seven angels at the divine throne from Tsifry. In Tsifry one can also find the explanation of three magical words that confirmed the membership to both the palata and a lodge, since the number three is the symbol of Trinity, i.e. of "небесное знание" (heavenly knowledge). In the light of this, the numeral and the linguistic symbols that Remizov uses in both his life and literature seem less like a parody and more like an attempt to form a new esoteric mystical theory on the basis of the old existing ones and to build his own magical school, a school which would help him to create a new reality as well as to recreate the past.

In his manifesto "Letter as such", V. Hlebnikov claims that should writers submit to their native mystical language, a mystical union would occur between people and their land, since "number is a true 
side of a letter, and the aim of a writer is to reveal that side" (Hlebnikov 1983: 119). One can argue that Remizov's book adheres very closely to Hlebnikov's idea. Lines of words in Azbuka and repetitions of numbers in Tsifry, which seem meaningless at first glance, are intended, just as does transrational language (zaum), to get to the original rhythmic power of language. Azbuka, Tsifry and Sunduk help the reader to feel the force of language through which it has its strength to create reality. Based on the example of these chapters, one can see how Remizov tries to replace the everyday words designed to describe reality with his own language, which is constructed of semantically meaningful letters, sounds and numbers, and which has the power to create. However, Remizov's aim is different from that of the Futurists. ${ }^{14}$ Remizov does not try to change the world or the Future. In his search for a hidden mystical creative side of language, he, like Cyril, the creator of the glagolitic alphabet, is trying to reveal the divine morality, пробудить в душе человеческое. It seems to me that both Rossiya $v$ pis'menah and Obez'yan'ya palata are but two sides of this attempt at linguistic symbolic enlightenment, the two sides that help understand one another. It is true that Remizov's use of glagolitic tainopis', his Kabbalistic pictures, and his playing with the language in Azbuka are but the components of a game he played his entire life; yet through this game the writer raises serious questions about the moral role of language in human life. "A wanderer on the ways of a word", a strong believer, Remizov perceives language as mystical Logos, a living being in which letters, sounds and numbers are vivid components. For Remizov such a view of language goes hand in hand with his aim in writing Rossiya $v$ pis'menah: to revive the dead Past, to create the New which is but a recreation of the Old, and to fill this New by the old light of God's morality.

\section{References}

Bogomolov, Nikolaj 1999 = Богомолов, Николай. Русская литература начала двадиатого века и оккультизм. Москва: Новое литературное обозрение.

Carlson, Maria 1993. No Religion Higher Than Truth: A History of the Theosophical Movement in Russia. New Jersey: Princeton University Press.

14 The same opinion can be seen in G. Slobin's book Remizov's Fictions: 19001921. Slobin says that "although Remizov's approach to linguistic innovation brought him close to the Futurists, especially to Velemir Hlebnikov, [...] translanguage was not his goal" (Slobin 1991: 31). 
Eco, Umberto 1998 = Эко, Умберто. Маятник Фуко. Москва: Ex Libris.

Faivre, Antoine 1992. Ancient and Medieval sources of modern esoteric movements. In: Faivre, Antoine; Needleman, Jacob (eds.), Modern Esoteric Spirituality. New York: Crossroad, 1-70.

Gumilev, Nikolaj 1987 = Гумилев, Николай. Избранное. Ленинград: Советский писатель.

Idel, Moshe 1988. Kabbalah: New Perspectives. New Haven: Yale University Press.

- 1992. The magical and neoplatonic interpretations of the Kabbalah in the Renaissance. In: Ruderman, David B. (ed.), Essential Papers on Jewish Culture in Renaissance and Baroque Italy. New York: New York University Press, 107-169.

Hlebnikov, Velemir 1983. Selected Works. New Haven: Yale University Press.

Kodrianskaya, Natalya 1957. Alexej Remizov. Paris.

Meyrink, Gustav 1992 = Майринк, Гюстав. Мастер Леонард. Иностранная Лumepamypa 3: 19-46.

Mathers, Samuel Liddell MacGregor (ed.) 1989. The Key of Solomon the King: Clavicula Salomonis. Maine: Samuel Weiser.

Mints, Zara G. 1979 = Минц, Зара. О некоторых "неомифологических" текстах в творчестве русских символистов. In: Минц, 3. Г. (ed.), Творчество А. А. Блока и русская культура ХХ века: Блоковский сборник 3. Тарту: Издательство Тартуского университета, 76-120.

Obatnina, Jelena 1996 = Обатнина, Елена. Обезьянья великая и волная палата: игра и ее парадигмы. Новое Литературное Обозрение 17: 185-218.

Papus 2000. Quabalah: Secret Tradition of the West. Maine: Weisser.

Rabinovich, Vadim $1979=$ Рабинович, Вадим. Алхимия как феномен средневековой культуры. Москва: Наука.

Reuchlin, Johannes 1987. De Arte Cabalistica. New York: Arcana Publishers.

Remizov, Alexej 1982. Rossiya v pis'menah. New York: Russika Publishers.

Rosenthal, Bernice (ed.) 1997. The Occult in Russian and Soviet Culture. Ithaca: Cornell University Press.

Ruderman, David (ed.) 1992. Essential Papers on Jewish Culture in Renaissance and Baroque Italy. New York: New York University Press.

Savelieva, Liudmila 1994 = Савельева, Людмила. Евангелический текст 6 русской литературе. Петрозаводск: Издательство Петрозаводского университета.

Serkov, Andrej 1997 = Серков, Андрей. История русского масонства: $1845-$ 1945. Санкт-Петербург: Издательство им. Н. Новикова.

Schmid, Ulrich 1999. A Symbolist under Soviet Rule: Sologub's Late Poetry. Slavic and East European Journal 43(4): 636-649.

Shklovskij, Viktor $2000=$ Шкловский, Виктор. Гамбургский счет. СанктПетербург: Limbus Press.

Sholem, Gershom 1941. Kabbalah. New York: New York Times Books Co.

- 1961. Major Trends in Jewish Mysticism. Schocken Books.

Slobin, Greta Nachtailer (ed.) 1986. Aleksej Remizov: Approaches to a Protean Writer. (UCLA Slavic Studies 16.) Columbus: Slavica. 
- 1991. Remizov's Fictions: 1900-1921. Indiana: Northern Illinois University Press.

Tolstoj, Leo 1995. War and Peace. New York: Random House.

Yates, Frances Amelia 1964. Giordano Bruno and the Hermetic Tradition. London: Routledge and K. Paul.

\section{Проблема языка и реальности в русском модернизме: концепция миротворчества в "Россия в Письменах" Алексея Ремизова}

Статья рассматривает литературный проект Алексея Ремизова Россия в Письменах с точки зрения общего отношения Серебрянного века к лингвистической символике и семиотике языка как к “божественному глаголу”, то есть магическому орудию для создания окружающей реальности. Евангельскую концепцию “в начале было Слово" Ремизов представляет как магическую и мистическую концепцию власти языка над реальностью, и пытается в своем произведении доказать это предположение через восстановление реалий российского прошлого с помощью симбиоза букв и цифр, бессмысленных на первый взгляд, но обладающих, согласно Ремизову, скрытым магическим смыслом.

На мой взгляд, данная интерпретация концепции власти языка над реальностью близка доктрине так называемой магической Каббалы. Статья анализирует теорию магической Каббалы, рассматривает интерпретацию и практическое применение этой теории в поэтической идеологии Серебрянного века, и анализирует книгу Ремизова как пример использования этой теории в русской литературе начала двадцатого века.

\section{Keele ja reaalsuse probleem vene modernismis: mirotvorchestvo mõiste Aleksei Remizovi raamatus "Rossija v pismenah"}

Vaadeldakse Aleksei Remizovi kirjanduslikku projekti Rossija v pismenah Hõbeajastu kontekstis, kus lingvistilisse sümboolikasse ja keelesemiootikasse suhtuti kui "jumalikku kõnesse", st vaadeldi seda teatud maagilise vahendina ümbritseva reaalsuse loomisel. Remizov mõtestab evangeeliumi "alguses oli Sõna" lahti kui keele reaalsuse üle valitsemise maagilise ja müstilise kontseptsiooni ning püüab oma teoses seda väidet tõestada, taastades vene mineviku reaaliaid esmapilgul mõttetute (kuid Remizovi järgi varjatud maagilist mõtet kandvate) tähtede ja arvude sümbioosi abil. 
Autori arvates on taoline keele reaalsuse üle valitsemise kontseptsiooni tõlgendus lähedane nn maagilisele Kabbalale. Artiklis analüüsitakse maagilise Kabbala teooriat, selle teooria tõlgendust ja praktilist rakendust Hõbeajastu poeetilises ideoloogias. Remizovi teost vaadeldakse sel foonil kui antud teooria kasutamise näidet vene kahekümnenda sajandi alguse kirjanduses. 